\title{
CPP-ZFN: A potential DNA-targeting anti-malarial drug
}

Vikrant Nain ${ }^{1 *}$, Shakti Sahi ${ }^{1 *}$, Anju Verma ${ }^{2}$

\begin{abstract}
Background: Multidrug-resistant Plasmodium is of major concern today. Effective vaccines or successful applications of RNAi-based strategies for the treatment of malaria are currently unavailable. An unexplored area in the field of malaria research is the development of DNA-targeting drugs that can specifically interact with parasitic DNA and introduce deleterious changes, leading to loss of vital genome function and parasite death.

Presentation of the hypothesis: Advances in the development of zinc finger nuclease (ZFN) with engineered DNA recognition domains allow us to design and develop nuclease of high target sequence specificity with a mega recognition site that typically occurs only once in the genome. Moreover, cell-penetrating peptides (CPP) can cross the cell plasma membrane and deliver conjugated protein, nucleic acid, or any other cargo to the cytoplasm, nucleus, or mitochondria. This article proposes that a drug from the combination of the CPP and ZFN systems can effectively enter the intracellular parasite, introduce deleterious changes in its genome, and eliminate the parasite from the infected cells.

Testing the hypothesis: Availability of a DNA-binding motif for more than 45 triplets and its modular nature, with freedom to change number of fingers in a ZFN, makes development of customized ZFN against diverse target DNA sequence of any gene feasible. Since the Plasmodium genome is highly AT rich, there is considerable sequence site diversity even for the structurally and functionally conserved enzymes between Plasmodium and humans. CPP can be used to deliver ZFN to the intracellular nucleus of the parasite. Signal-peptide-based heterologous protein translocation to Plasmodium-infected RBCs (iRBCs) and different Plasmodium organelles have been achieved. With successful fusion of CPP with mitochondrial- and nuclear-targeting peptides, fusion of CPP with 1 more Plasmodium cell membrane translocation peptide seems achievable.

Implications of the hypothesis: Targeting of the Plasmodium genome using ZFN has great potential for the development of anti-malarial drugs. It allows the development of a single drug against all malarial infections, including multidrug-resistant strains. Availability of multiple ZFN target sites in a single gene will provide alternative drug target sites to combat the development of resistance in the future.
\end{abstract}

\section{Background}

Malaria is the most devastating human parasitic infection. It threatens half of the world's population, killing more than 1 million people each year [1,2]. Malaria species vary widely in epidemiology and clinical manifestation $[3,4]$. No effective malaria vaccine is currently available, and drug resistance has been implicated in the spread and re-emergence of the disease [5-7]. Artemisinin drugs, an essential component of treatment for

\footnotetext{
*Correspondence: vikrant@gbu.ac.in; shaktis@gbu.ac.in

'School of Biotechnology, Gautam Buddha University, Greater Noida-201308, India

Full list of author information is available at the end of the article
}

multidrug-resistant falciparum malaria, have recently shown signs of decreased efficacy in combination drug therapy [8-12].

With the availability of complete genome sequences of Plasmodium, humans and Anopheles-hosts of the parasite, development of novel effective anti malarial drugs was envisioned [13]. However, in spite of eclipse of more than one decade no significant advances have been made in the area of genomics based anti-malarial drug development. Plasmodium genome is highly AT rich as compared to human genome and this opens up opportunities for development of DNA-targeting drugs that can specifically interact with parasite DNA and introduce deleterious changes
Ciomed Central

() 2010 Nain et al; licensee BioMed Central Ltd. This is an Open Access article distributed under the terms of the Creative Commons Attribution License (http://creativecommons.org/licenses/by/2.0), which permits unrestricted use, distribution, and reproduction in any medium, provided the original work is properly cited. 
leading to loss of vital genome function and parasite death. Some DNA targeting drugs such as Aminoquinolines, azaterphenyl diamidines, adozelesin and bizelesin shows anti plasmodium activity, however the problem of cytotoxicity and potential threat of mutagenesis in human DNA is major limiting factor [14-16].

\section{Presentation of the hypothesis}

Advances in the development of zinc finger nuclease (ZFN) with engineered DNA recognition domains allow us to design and develop nuclease of high target sequence specificity [17-19]. In vivo application of ZFN with a single mega recognition sequence leads to target gene modification in Drosophila, zebra fish, mice, Arabidopsis, rice, tobacco, and other genomes [20-25], with a gene targeting frequency upto $80 \%$ of ZFN-transfected cells [26]. Cell-penetrating peptides (CPP) provide a novel mechanism for intracellular macromolecular delivery $[27,28]$, CPP are known to cross the cell plasma membrane in a nonspecific manner and deliver conjugated protein, nucleic acid, or any other cargo to the cytoplasm, nucleus, or mitochondria, depending on the additional signal sequences present [27,29-33].
In this article it is believed that a drug from the combination of CPP and ZFN can effectively enter the intracellular parasite, introduce deleterious changes in its genome, and eliminate the parasite from infected cells. Preliminary studies of therapeutic application of ZFN-based drugs against HIV and hepatitis B virus further strengthen the prospects of ZFN-based antimalarial drug development [26,34]. ZFN mediated disruption of HIV co-receptor CCR5 in human CD4(+) T cells confers resistance to HIV-1 infection [22,26,35]. While ZFN therapeutic against hepatitis $B$ virus intended to directly target and inactivate episomal DNA viral genomes [34]. In the present article, the use of ZFN to specifically target the Plasmodium genome with the aim to knock out vital parasite genes is proposed (Figure 1).

\section{Key hypothesis/assumptions}

1. ZFN will specifically target the Plasmodium genome.

2. ZFN can cross the plasma membrane barrier of the host and Plasmodium cell.

3. DNA double-strand break will kill Plasmodium.

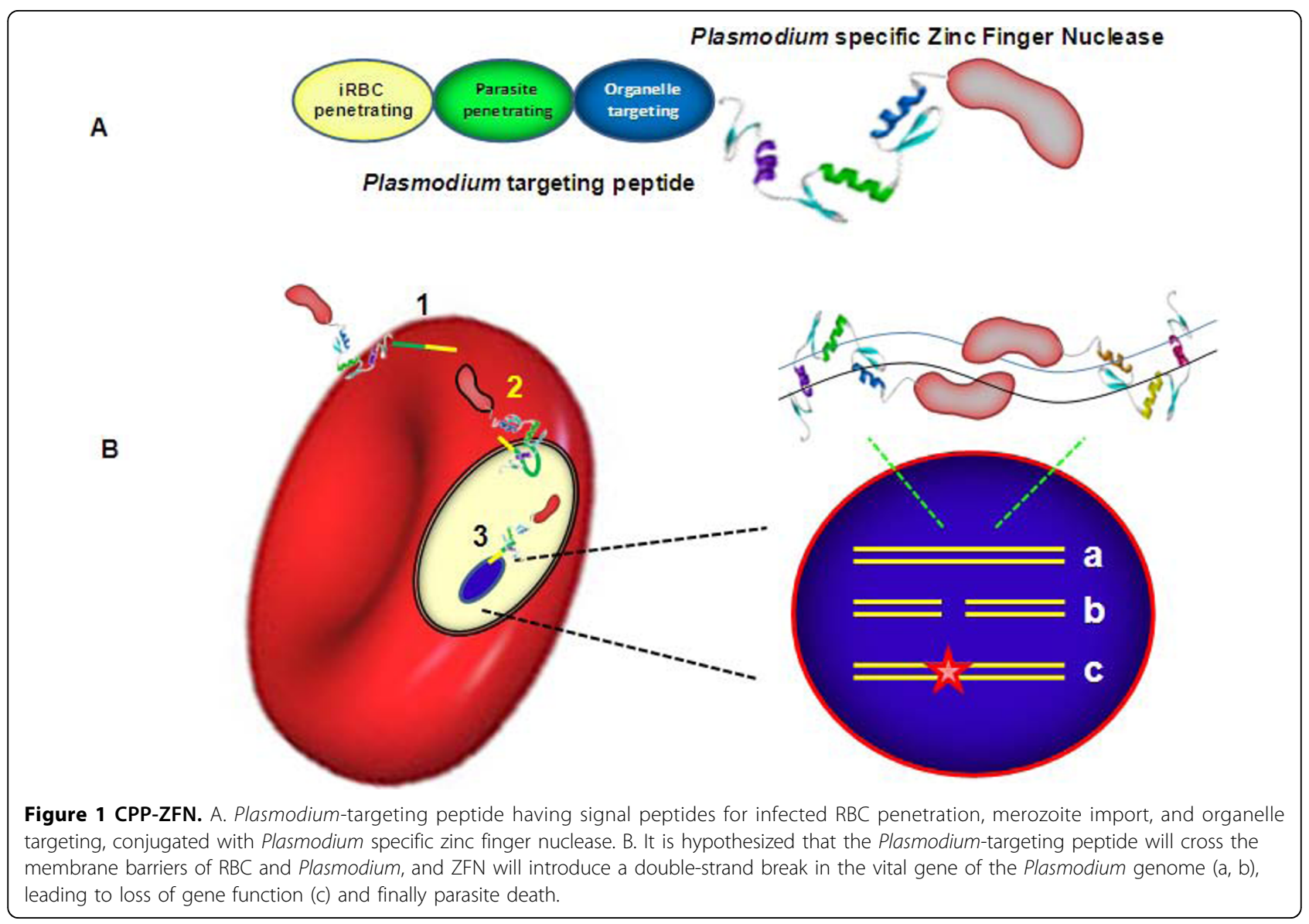




\section{Testing of the hypothesis}

\section{Designing specific ZFN}

ZFN can be designed specifically against any gene in any genome [21,22,36-38]. C2H2-type zinc finger proteins consist of an array of protein fingers stabilized by zinc ion, with each finger recognizing a specific triplet of DNA sequence [17]. Protein fingers specific for more than 45 triplets are known and have a modular nature, with freedom to change number of fingers, which makes the development of customized ZFP against diverse target DNA sequence feasible (Additional file 1). A combination of 6 fingers recognizes a DNA sequence of 18 nucleotides that have a probability of occurring after $4^{18}$ nucleotides, much more than the human genome size (3000 MB). Hence, a ZFN designed against the Plasmodium genome have negligible probability of randomly occurring in the human genome. ZFN designing and validation tools, and CompoZr ${ }^{\circledR}$ custom ZFN designing, assembling, and validation service, reduce the time required for the development of ZFN against new targets [39-42].

\section{Selection of ZFN target sites}

Availability of complete genome sequences have helped identify different anti-malarial drug targets, such as histone deacetylase, aspartic proteases or plasmepsins, aminopeptidases, and the purine salvage enzyme hypoxanthine-xanthine-guanine phosphoribosyltransferase, within the parasite [43-46]. However, limited knowledge on the structure of most of these genes, and on the conservation of basic eukaryotic cellular machinery in Plasmodium and humans, hampers the conventional enzyme-targeting drug design procedures [47]. The Plasmodium genome is highly AT rich, in contrast to the human genome that is GC-rich; this provides considerable sequence (ZFN target) site diversity even for the structurally and functionally conserved enzymes between Plasmodium and humans. ZFN technology can utilize this sequence diversity and overcome the limitations of traditional drug-design approaches, which are confined to parasite-specific metabolic pathways. Moreover, ZFN can be designed against the target site conserved across different Plasmodium species (Additional file 2).

\section{Delivery of ZFN to the target site}

Discovery of cell-penetrating peptides provides a novel way of delivering therapeutic molecules to the target cell or organelles [27-29,31,48-51]. A major challenge in ZFN delivery is developing a peptide that can transfer conjugated ZFN through cell membranes of Plasmodium-infected RBC (iRBC), the parasite, parasitophorous vacuole, and its organelles (apicoplast, mitochondria, or nucleus).

\section{Delivery to RBCs}

CPP are generally considered to deliver cargo to cells in a nonspecific manner [51]. iRBCs have different surface proteins and charge that can be utilized for making strategies for specific ZFN delivery. As a matter of evidence, P1 peptides specifically target iRBCs [52], and DPT-sh1/ sh2 CPP specifically recognize and deliver conjugated heterologous proteins to iRBCs [53].

\section{Translocation from host cell cytoplasm to Plasmodium}

Following CPP-mediated ZFN delivery to RBCs, the next challenge is to cross the parasite cell membrane and interact with its DNA. CPP-mediated protein delivery to different intracellular organelles such as the nucleus and mitochondria have been reported $[54,55]$. Intracellular Plasmodium imports a number of proteins, such as heme, $\delta$-aminolaevulinate (ALA), and peroxiredoxin 2 , from the host cytoplasm [56-58], which could be a valuable source of signal sequences for translocation of ZFN from the host cytoplasm to the parasite.

\section{Targeting to Plasmodium organelles}

Once ZFN enters the Plasmodium, it has to be directed towards any of its organelles-apicoplast, mitochondria, or nucleus-which have their own genome. Use of the yeast GAL4 nuclear localization signal leads to translocation of green florescent protein (GFP) to Plasmodium nucleus and shows conservation of nuclear localization signal in Plasmodium and other eukaryotes [59]. GFP was fused with the $\mathrm{N}$-terminal sequence of heat shock protein (PfHsp); PfHsp-GFP was targeted to Plasmodium mitochondria [60]; and apicoplast targeting was achieved by using the signal sequence of acyl carrier protein [61-63].

Availability of iRBCs penetrating peptide [53]; Plasmodium import proteins [56-58]; and Plasmodium apicoplast, mitochondria, and nucleus targeting signal sequences [59-63] provides building blocks for the development of a Plasmodium-targeting, multiple-membrane-traversing peptide. Following the successful fusion of CPP with mitochondrial- and nuclear-targeting peptides [54,64,65], fusion of CPP with 1 more Plasmodium cell membrane translocation peptide appears to be achievable.

\section{Hydrolysis of double-stranded DNA}

A ZFN-induced double-strand break (DSB) triggers either of the 2 DNA repair processes: error-prone nonhomologous end joining (NHEJ) and error-proof homology-dependent repair (HDR). Genetic and biochemical evidence support the hypothesis that NHEJ and HR are 2 independent and competing mechanisms for DSB repair in diploid organisms[66,67]. Being in the haploid stage in humans, HDR must be absent in Plasmodium and the error-prone repair mechanism of NHEJ often results in localized mutations due to deletion and/or 
insertion of short sequences at the DSB site, thereby resulting in disruption of functional gene expression in Plasmodium. Moreover, AT-specific DNA alkylating drugs have previously shown anti $P$. falciparum activity and recent advances in ZFN directed multiple DSB resulting in chromosomal deletions further strengthens the prospects of DNA targeting anti malaria drug [68-70].

\section{Experimental validation of ZFN therapeutic efficacy}

An in silico designed and in vitro validated ZFN is to be evaluated for bioavailability, potency, in vivo localization and their specificity for parasite over human DNA. A microfluorimetric method using PicoGreen ${ }^{\circ}$ can be used for assessing susceptibility of parasites to CPP-ZFN compounds [71,72]. Since all ZFN consist of nuclease domain of FokI restriction enzyme so FokI antisera can be used for immuno-localization and quantification of ZFN [73]. Alternatively ZFN are designed to have an additional small protein tag, such as Flag or His tag and subsequently detected by fusion tag specific antibodies [74]. The quantification of DSB repair loci induced by ZFN provide genotoxicity assay, to test any off target effect of parasite specific ZFN over human genome $[75,76]$.

\section{Implications of the hypothesis}

The major advantage of ZFN technology is that it enormously increases the number of drug targets because it can utilize the vast sequence diversity among structurally and functionally conserved enzymes of human and Plasmodium proteins. Prolonged use of any drug forces the evolution of drug-resistant parasite strains, and ZFN would not be an exception. Another advantage of ZFN technology is that it allows convenient development of new ZFN against other target sites (18 bp) in the same gene. The resulting new drug will be effective even against resistant strains, providing ample alternatives for drug resistance management.

Unlike common drugs that directly inhibit the target protein, ZFN technology is focused on inhibiting the synthesis of a functional target protein; thus, its effect will be slower than inhibitor drugs. This constraint may not be a concern as ZFN utilizes the difference between human and Plasmodium gene sequences, so every vital gene becomes a potential drug target. Selection of genomic locus coding for short half-life will greatly enhance the response time of ZFN-based drugs.

Availability of newer drug targets to virtually all Plasmodium genes provides the opportunity to find conserved sites in vital genes and develop a single drug against all malarial infections, including multidrug-resistant strains, for worldwide use. CPP-mediated protein delivery is an established method that can be used for delivery of the newly designed ZFN. CPP-ZFN promises to be a safe and sustainable drug for malaria intervention.

\section{Conflict of interests}

The authors declare that they have no competing interests.

\section{Additional material}

Additional file 1: Designing of target-site-specific zinc finger nuclease (ZFN) through modular assembly. With the target site specific ZFP designing by incorporating zinc finger helices, linkers, $N$ and C-terminal fixed sequences, ZFP binding to target site can be validated by gel shift assay. As ZFP do not have nuclease activity it does not cut the target sequence. Incorporation of nuclease domain of Fokl constitutes the functional ZFN that can be validated by in vitro digestion of DNA with target sequence.

Additional file 2: Designing of zinc finger nuclease (ZFN) against a conserved site in lactate dehydrogenase genes of $P$. falciparum and $\boldsymbol{P}$. vivax. Two ZFN designed on opposite strands will introduce a nick in the spacer region, leading to a double-strand break. ELISA data of multitarget specificity assay for all triplets, black bars represent target oligonucleotides, while white bars represent oligonucleotide pools with a particular $5^{\prime}$ nucleotide. The height of each bar represents the relative specificity of the protein for each target [42].

\section{Acknowledgements}

The authors are thankful to Drs. Jane Carlton and Steven Sullivan, New York University Langone Medical Center, New York, for their critical reading of the manuscript and for providing valuable suggestions that increased scientific content and presentation of the manuscript.

\section{Author details}

'School of Biotechnology, Gautam Buddha University, Greater Noida-201308, India. ${ }^{2}$ School of Biological Sciences, University of Missouri, Kansas City, MO64110, USA.

\section{Authors' contributions}

VN: conceived the idea. AV, SS, and VN: involved in intellectual discussions, formulated the hypothesis, and wrote the manuscript. SS and VN: created graphical presentations and designed ZFN against the target site. All authors read and approved the final manuscript.

Received: 22 June 2010 Accepted: 16 September 2010 Published: 16 September 2010

\section{References}

1. Phillips RS: Current status of malaria and potential for control. Clin Microbiol Rev 2001, 14:208-226.

2. Vitoria M, Granich R, Gilks CF, Gunneberg C, Hosseini M, Were W, Raviglione M, De Cock KM: The global fight against HIV/AIDS, tuberculosis, and malaria: current status and future perspectives. Am J Clin Pathol 2009, 131:844-848.

3. Prugnolle F, Durand P, Neel C, Ollomo B, Ayala FJ, Arnathau C, Etienne L, Mpoudi-Ngole E, Nkoghe D, Leroy E, Delaporte E, Peeters M, Renaud F: African great apes are natural hosts of multiple related malaria species, including Plasmodium falciparum. Proc Natl Acad Sci USA 2010, 107:1458-1463.

4. Jeffares DC, Pain A, Berry A, Cox AV, Stalker J, Ingle CE, Thomas A, Quail MA, Siebenthall K, Uhlemann AC, Kyes S, Krishna S, Newbold C, Dermitzakis ET, Berriman M: Genome variation and evolution of the malaria parasite Plasmodium falciparum. Nat Genet 2007, 39:120-125.

5. Escalante AA, Smith DL, Kim Y: The dynamics of mutations associated with anti-malarial drug resistance in Plasmodium falciparum. Trends Parasitol 2009, 25:557-563. 
6. Guerin PJ, Bates SJ, Sibley CH: Global resistance surveillance: ensuring antimalarial efficacy in the future. Curr Opin Infect Dis 2009, 22:593-600.

7. Witkowski B, Berry A, Benoit-Vical F: Resistance to antimalarial compounds: methods and applications. Drug Resist Updat 2009, 12:42-50.

8. Denis MB, Tsuyuoka R, Lim P, Lindegardh N, Yi P, Top SN, Socheat D, Fandeur T, Annerberg A, Christophel EM, Ringwald P: Efficacy of artemether-lumefantrine for the treatment of uncomplicated falciparum malaria in northwest Cambodia. Trop Med Int Health 2006, 11:1800-1807.

9. Noedl H, Se Y, Schaecher K, Smith BL, Socheat D, Fukuda MM: Evidence of artemisinin-resistant malaria in western Cambodia. NEJM 2008, 359:2619-2620.

10. Denis MB, Tsuyuoka R, Poravuth Y, Narann TS, Seila S, Lim C, Incardona S, Lim P, Sem R, Socheat D, Christophel EM, Ringwald P: Surveillance of the efficacy of artesunate and mefloquine combination for the treatment of uncomplicated falciparum malaria in Cambodia. Trop Med Int Health 2006, 11:1360-1366.

11. Alker AP, Lim P, Sem R, Shah NK, Yi P, Bouth DM, Tsuyuoka R, Maguire JD, Fandeur T, Ariey F, Wongsrichanalai C, Meshnick SR: Pfmdr1 and in vivo resistance to artesunate-mefloquine in falciparum malaria on the Cambodian-Thai border. Am J Trop Med Hyg 2007, 76:641-647.

12. Dondorp AM, Yeung S, White L, Nguon C, Day NP, Socheat D, von Seidlein L: Artemisinin resistance: current status and scenarios for containment. Nat Rev Microbiol 2010, 8:272-280.

13. Gardner MJ, Hall N, Fung E, White O, Berriman M, Hyman RW, Carlton JM, Pain A, Nelson KE, Bowman S, Paulsen IT, James K, Eisen JA, Rutherford K, Salzberg SL, Craig A, Kyes S, Chan MS, Nene V, Shallom SJ, Suh B, Peterson J, Angiuoli S, Pertea M, Allen J, Selengut J, Haft D, Mather MW Vaidya AB, Martin DM, Fairlamb AH, Fraunholz MJ, Roos DS, Ralph SA, McFadden Gl, Cummings LM, Subramanian GM, Mungall C, Venter JC, Carucci DJ, Hoffman SL, Newbold C, Davis RW, Fraser CM, Barrell B: Genome sequence of the human malaria parasite Plasmodium falciparum. Nature 2002, 419:498-511.

14. Wenzel NI, Chavain N, Wang Y, Friebolin W, Maes L, Pradines B, Lanzer M, Yardley V, Brun R, Herold-Mende C, Biot C, Tolth K, Davioud-Charvet E: Antimalarial versus Cytotoxic properties of dual drugs derived from 4aminoquinolines and mannich bases: interaction with DNA. J Med Chem 2010, 53:3214-3226.

15. Hu L, Arafa RK, Ismail MA, Patel A, Munde M, Wilson WD, Wenzler T, Brun R, Boykin DW: Synthesis and activity of azaterphenyl diamidines against Trypanosoma brucei rhodesiense and Plasmodium falciparum. Bioorg Med Chem 2009, 17:6651-6658.

16. Woynarowski JM, Krugliak M, Ginsburg H: Pharmacogenomic analyses of targeting the AT-rich malaria parasite genome with AT-specific alkylating drugs. Mol Biochem Parasitol 2007, 154:70-81.

17. Carroll D: Progress and prospects: zinc-finger nucleases as gene therapy agents. Gene Ther 2008, 15:1463-1468.

18. Kandavelou K, Mani M, Durai S, Chandrasegaran S: "Magic" scissors for genome surgery. Nat Biotechnol 2005, 23:686-687.

19. Cathomen T, Joung JK: Zinc-finger nucleases: the next generation emerges. Mol Ther 2008, 16:1200-1207.

20. Foley JE, Maeder ML, Pearlberg J, Joung JK, Peterson RT, Yeh JR: Targeted mutagenesis in zebrafish using customized zinc-finger nucleases. Nat Protoc 2009, 4:1855-1867

21. Kandavelou K, Chandrasegaran S: Custom-designed molecular scissors for site-specific manipulation of the plant and mammalian genomes. Methods Mol Biol 2009, 544:617-636.

22. Kim HJ, Lee HJ, Kim H, Cho SW, Kim JS: Targeted genome editing in human cells with zinc finger nucleases constructed via modular assembly. Genome Res 2009, 19:1279-1288.

23. Lee HJ, Kim E, Kim JS, Radecke S, Radecke F, Cathomen T, Schwarz K: Targeted chromosomal deletions in human cells using zinc finger nucleases. Genome Res 2009, 20:81-89.

24. Remy S, Tesson L, Menoret S, Usal C, Scharenberg AM, Anegon I, Santiago Y, Chan E, Liu PQ, Orlando S, Zhang L, Urnov FD, Holmes MC, Guschin D, Waite A, Miller JC, Rebar EJ, Gregory PD, Klug A, Collingwood TN, Wu J, Kandavelou K, Chandrasegaran S, Mani M, Kandavelou K, Dy FJ, Durai S, Chandrasegaran S: Zinc-finger nucleases: a powerful tool for genetic engineering of animals. Transgenic Res 2009, 26:26

25. Shukla VK, Doyon Y, Miller JC, DeKelver RC, Moehle EA, Worden SE, Mitchell JC, Arnold NL, Gopalan S, Meng X, Choi VM, Rock JM, Wu YY,
Katibah GE, Zhifang G, McCaskill D, Simpson MA, Blakeslee B, Greenwalt SA, Butler HJ, Hinkley SJ, Zhang L, Rebar EJ, Gregory PD, Urnov FD: Precise genome modification in the crop species Zea mays using zinc-finger nucleases. Nature 2009, 459:437-441.

26. Perez EE, Wang J, Miller JC, Jouvenot Y, Kim KA, Liu O, Wang N, Lee G, Bartsevich W, Lee YL, Guschin DY, Rupniewski I, Waite AJ, Carpenito C, Carroll RG, Orange JS, Urnov FD, Rebar EJ, Ando D, Gregory PD, Riley JL, Holmes MC, June CH: Establishment of HIV-1 resistance in CD4+ T cells by genome editing using zinc-finger nucleases. Nat Biotechnol 2008, 26:808-816.

27. Sawant $R$, Torchilin $V$, Raagel $H$, Saalik P, Pooga M, Munst B, Patsch C, Edenhofer F, Gitton Y, Tibaldi L, Dupont E, Levi G, Joliot A, Edenhofer F, Meade BR, Dowdy SF, Gump JM, Dowdy SF, Meade BR, Dowdy SF, Dong X, Wang JN, Huang YZ, Guo LY, Kong X, Murriel CL, Dowdy SF: Intracellular transduction using cell-penetrating peptides. Mol Biosyst 2009, 6:628-640

28. Gump JM, Dowdy SF, Meade BR, Dowdy SF, Dong X, Wang JN, Huang YZ, Guo LY, Kong X, Murriel CL, Dowdy SF: TAT transduction: the molecular mechanism and therapeutic prospects. Trends Mol Med 2007, 13:443-448.

29. Ward B, Seal BL, Brophy CM, Panitch A, Sawant R, Torchilin V, Raagel H, Saalik P, Pooga M, Munst B, Patsch C, Edenhofer F, Gitton Y, Tibaldi L, Dupont E, Levi G, Joliot A, Edenhofer F, Meade BR, Dowdy SF, Gump JM, Dowdy SF, Meade BR, Dowdy SF, Dong X, Wang JN, Huang YZ, Guo LY, Kong $X$, Murriel $\mathrm{CL}$, Dowdy SF: Design of a bioactive cell-penetrating peptide: when a transduction domain does more than transduce. J Pept Sci 2009, 15:668-674.

30. Gitton $Y$, Tibaldi L, Dupont E, Levi G, Joliot A, Edenhofer F, Meade BR, Dowdy SF, Gump JM, Dowdy SF, Meade BR, Dowdy SF, Dong X, Wang JN, Huang YZ, Guo LY, Kong X, Murriel CL, Dowdy SF: Efficient CPP-mediated Cre protein delivery to developing and adult CNS tissues. BMC Biotechnol 2009, 9:40.

31. Fonseca SB, Pereira MP, Kelley SO: Recent advances in the use of cellpenetrating peptides for medical and biological applications. Adv Drug Deliv Rev 2009, 61:953-964.

32. Meade BR, Dowdy SF, Gump JM, Dowdy SF, Meade BR, Dowdy SF, Dong X, Wang JN, Huang YZ, Guo LY, Kong X, Murriel CL, Dowdy SF: Enhancing the cellular uptake of siRNA duplexes following noncovalent packaging with protein transduction domain peptides. Adv Drug Deliv Rev 2008, 60:530-536.

33. Meade BR, Dowdy SF, Dong X, Wang JN, Huang YZ, Guo LY, Kong X, Murriel $C L$, Dowdy SF: Exogenous siRNA delivery using peptide transduction domains/cell penetrating peptides. Adv Drug Deliv Rev 2007, 59:134-140.

34. Cradick TJ, Keck K, Bradshaw S, Jamieson AC, McCaffrey AP: Zinc-finger nucleases as a novel therapeutic strategy for targeting hepatitis $b$ virus DNAs. Mol Ther 2010, 2010:16.

35. Holt N, Wang J, Kim K, Friedman G, Wang X, Taupin V, Crooks GM, Kohn DB, Gregory PD, Holmes MC, Cannon PM: Human hematopoietic stem/progenitor cells modified by zinc-finger nucleases targeted to CCR5 control HIV-1 in vivo. Nat Biotech 2010, 28:839-847.

36. Cai CQ, Doyon Y, Ainley WM, Miller JC, Dekelver RC, Moehle EA, Rock JM, Lee YL, Garrison R, Schulenberg L, Blue R, Worden A, Baker L, Faraji F, Zhang L, Holmes MC, Rebar EJ, Collingwood TN, Rubin-Wilson B, Gregory PD, Urnov FD, Petolino JF: Targeted transgene integration in plant cells using designed zinc finger nucleases. Plant Mol Biol 2009, 69:699-709.

37. Pruett-Miller SM, Connelly JP, Maeder ML, Joung JK, Porteus MH: Comparison of zinc finger nucleases for use in gene targeting in mammalian cells. Mol Ther 2008, 16:707-717.

38. Wu J, Kandavelou K, Chandrasegaran S, Mashimo T, Takizawa A, Voigt B, Yoshimi K, Hiai H, Kuramoto T, Serikawa T: Custom-designed zinc finger nucleases: what is next? Cell Mol Life Sci 2007, 64:2933-2944.

39. Jayakanthan M, Muthukumaran J, Chandrasekar S, Chawla K, Punetha A, Sundar D: ZifBASE: a database of zinc finger proteins and associated resources. BMC Genomics 2009, 10:421.

40. Fu F, Sander JD, Maeder M, Thibodeau-Beganny S, Joung JK, Dobbs D, Miller L, Voytas DF: Zinc Finger Database (ZiFDB): a repository for information on $\mathrm{C}_{2} \mathrm{H} 2$ zinc fingers and engineered zinc-finger arrays. Nucleic Acids Res 2009, , 37 Database: D279-283.

41. Sander JD, Zaback P, Joung JK, Voytas DF, Dobbs D: Zinc Finger Targeter (ZiFiT): an engineered zinc finger/target site design tool. Nucleic Acids Res 2007, , 35 Web Server: W599-605. 
42. Mandell JG, Barbas CF: Zinc Finger Tools: custom DNA-binding domains for transcription factors and nucleases. Nucleic Acids Res 2006, , 34 Web Server: W516-523.

43. Na-Bangchang K, Karbwang J: Current status of malaria chemotherapy and the role of pharmacology in antimalarial drug research and development. Fundam Clin Pharmacol 2009, 23:387-409.

44. Choi SR, Mukherjee $P$, Avery MA: The fight against drug-resistant malaria: novel plasmodial targets and antimalarial drugs. Curr Med Chem 2008, 15:161-171.

45. Jana S, Paliwal J: Novel molecular targets for antimalarial chemotherapy. Int J Antimicrob Agents 2007, 30:4-10.

46. Gardiner DL, Skinner-Adams TS, Brown CL, Andrews KT, Stack CM, McCarthy JS, Dalton JP, Trenholme KR: Plasmodium falciparum: new molecular targets with potential for antimalarial drug development. Expert Rev Anti Infect Ther 2009, 7:1087-1098.

47. Dharia NV, Chatterjee A, Winzeler EA: Genomics and systems biology in malaria drug discovery. Curr Opin Investig Drugs 11:131-138.

48. Juliano RL, Alam R, Dixit V, Kang HM: Cell-targeting and cell-penetrating peptides for delivery of therapeutic and imaging agents. Wiley Interdiscip Rev Nanomed Nanobiotechnol 2009, 1:324-335.

49. Vives E, Schmidt J, Pelegrin A: Cell-penetrating and cell-targeting peptides in drug delivery. Biochim Biophys Acta 2008, 1786:126-138.

50. Morris MC, Deshayes S, Heitz F, Divita G: Cell-penetrating peptides: from molecular mechanisms to therapeutics. Biol Cell 2008, 100:201-217.

51. Torchilin VP: Tat peptide-mediated intracellular delivery of pharmaceutical nanocarriers. Adv Drug Deliv Rev 2008, 60:548-558.

52. Eda $K$, Eda $S$, Sherman IW: Identification of peptides targeting the surface of plasmodium falciparum-infected erythrocytes using a phage display peptide library. Am J Trop Med Hyg 2004, 71:190-195.

53. Guergnon J, Dessauge F, Dominguez V, Viallet J, Bonnefoy S, Yuste VJ, Mercereau-Puijalon O, Cayla X, Rebollo A, Susin SA, Bost PE, Garcia A: Use of penetrating peptides interacting with PP1/PP2A proteins as a general approach for a drug phosphatase technology. Mol Pharmacol 2006, 69:1115-1124

54. Vyas PM, Payne RM: TAT opens the door. Mol Ther 2008, 16:647-648.

55. Flierl A, Jackson C, Cottrell B, Murdock D, Seibel P, Wallace DC: Targeted delivery of DNA to the mitochondrial compartment via import sequence-conjugated peptide nucleic acid. Mol Ther 2003, 7:550-557.

56. Bonday ZQ, Taketani S, Gupta PD, Padmanaban G, Bonday ZQ, Dhanasekaran S, Rangarajan PN, Padmanaban G: Heme biosynthesis by the malarial parasite. Import of delta-aminolevulinate dehydrase from the host red cell. J Biol Chem 1997, 272:21839-21846.

57. Bonday ZQ, Dhanasekaran S, Rangarajan PN, Padmanaban G: Import of host delta-aminolevulinate dehydratase into the malarial parasite: identification of a new drug target. Nat Med 2000, 6:898-903.

58. Koncarevic S, Rohrbach P, Deponte M, Krohne G, Prieto JH, Yates J, Rahlfs S, Becker $\mathrm{K}$ : The malarial parasite Plasmodium falciparum imports the human protein peroxiredoxin 2 for peroxide detoxification. Proc Natl Acad Sci USA 2009, 106:13323-13328.

59. Wittayacom K, Uthaipibull C, Kumpornsin K, Tinikul R, Kochakarn T, Songprakhon $\mathrm{P}$, Chookajorn T: A nuclear targeting system in Plasmodium falciparum. Malar J 9:126.

60. Sato S, Rangachari K, Wilson RJ: Targeting GFP to the malarial mitochondrion. Mol Biochem Parasitol 2003, 130(2):155-158.

61. Stanway RR, Witt T, Zobiak B, Aepfelbacher M, Heussler VT: GFP-targeting allows visualization of the apicoplast throughout the life cycle of live malaria parasites. Biol Cell 2009, 101:415-430, 415 p following 430.

62. Tonkin CJ, Kalanon M, McFadden Gl: Protein targeting to the malaria parasite plastid. Traffic 2008, 9:166-175.

63. Tonkin CJ, Foth BJ, Ralph SA, Struck N, Cowman AF, McFadden Gl: Evolution of malaria parasite plastid targeting sequences. Proc Natl Acad Sci USA 2008, 105:4781-4785.

64. Horton KL, Stewart KM, Fonseca SB, Guo Q, Kelley SO: Mitochondriapenetrating peptides. Chem Biol 2008, 15:375-382.

65. Yoshikawa T, Sugita T, Mukai Y, Yamanada N, Nagano K, Nabeshi $H_{4}$ Yoshioka Y, Nakagawa S, Abe Y, Kamada H, Tsunoda S, Tsutsumi Y: Organelle-targeted delivery of biological macromolecules using the protein transduction domain: potential applications for peptide aptamer delivery into the nucleus. J Mol Biol 2008, 380:777-782.

66. Essers J, van Steeg H, de Wit J, Swagemakers SM, Vermeij M, Hoeijmakers JH, Kanaar R: Homologous and non-homologous recombination differentially affect DNA damage repair in mice. Embo $\mathrm{J}$ 2000, 19:1703-1710.

67. Liang F, Han M, Romanienko PJ, Jasin M: Homology-directed repair is a major double-strand break repair pathway in mammalian cells. Proc Natl Acad Sci USA 1998, 95:5172-5177.

68. Woynarowski JM, Krugliak M, Ginsburg H: Pharmacogenomic analyses of targeting the AT-rich malaria parasite genome with AT-specific alkylating drugs. Molecular and Biochemical Parasitology 2007, 154:70-81.

69. Lee HJ, Kim E, Kim J-S: Targeted chromosomal deletions in human cells using zinc finger nucleases. Genome Research 2010, 20:81-89.

70. Sollu C, Pars K, Cornu TI, Thibodeau-Beganny S, Maeder ML, Joung JK, Heilbronn R, Cathomen T: Autonomous zinc-finger nuclease pairs for targeted chromosomal deletion. Nucl Acids Res 2010, gkq720..

71. Quashie NB, de Koning HP, Ranford-Cartwright LC: An improved and highly sensitive microfluorimetric method for assessing susceptibility of Plasmodium falciparum to antimalarial drugs in vitro. Malar J 2006, 5:95.

72. Corbett Y, Herrera L, Gonzalez J, Cubilla L, Capson TL, Coley PD, Kursar TA, Romero LI, Ortega-Barria E: A novel DNA-based microfluorimetric method to evaluate antimalarial drug activity. Am J Trop Med Hyg 2004, 70:119-124.

73. Beumer K, Bhattacharyya G, Bibikova M, Trautman JK, Carroll D: Efficient gene targeting in Drosophila with zinc-finger nucleases. Genetics 2006, 172:2391-2403.

74. Pruett-Miller SM, Reading DW, Porter SN, Porteus MH: Attenuation of zinc finger nuclease toxicity by small-molecule regulation of protein levels. PLOS Genet 2009, 5:e1000376.

75. Cornu Tl, Cathomen T: Quantification of zinc finger nuclease-associated toxicity. Methods Mol Biol 2010, 649:237-245.

76. Guschin DY, Waite AJ, Katibah GE, Miller JC, Holmes MC, Rebar EJ: A rapid and general assay for monitoring endogenous gene modification. Meth Mol Biol 2010, 649:247-256.

doi:10.1186/1475-2875-9-258

Cite this article as: Nain et al.: CPP-ZFN: A potential DNA-targeting antimalarial drug. Malaria Journal 2010 9:258.

\section{Submit your next manuscript to BioMed Central and take full advantage of:}

- Convenient online submission

- Thorough peer review

- No space constraints or color figure charges

- Immediate publication on acceptance

- Inclusion in PubMed, CAS, Scopus and Google Scholar

- Research which is freely available for redistribution 